Hydrol. Earth Syst. Sci. Discuss., 7, 4501-4533, 2010 www.hydrol-earth-syst-sci-discuss.net/7/4501/2010/ doi:10.5194/hessd-7-4501-2010

(c) Author(s) 2010. CC Attribution 3.0 License.
Hydrology and Earth System Sciences Discussions

\title{
Interpretation of GRACE data of the Nile Basin using a groundwater recharge model
}

H. C. Bonsor ${ }^{1}$, M. M. Mansour ${ }^{2}$, A. M. MacDonald ${ }^{1}$, A. G. Hughes ${ }^{2}$, R. G. Hipkin ${ }^{3}$, and T. Bedada ${ }^{3}$

${ }^{1}$ British Geological Survey, Murchison House, West Mains Road, Edinburgh, UK ${ }^{2}$ British Geological Survey, Kingsley Dunham Centre, Keyworth, Nottingham, UK

${ }^{3}$ Grant Institute, Edinburgh University, West Mains Road, Edinburgh, UK

Received: 3 June 2010 - Accepted: 5 July 2010 - Published: 9 July 2010

Correspondence to: H. C. Bonsor (helnso@bgs.ac.uk)

Published by Copernicus Publications on behalf of the European Geosciences Union.

HESSD

$7,4501-4533,2010$

Interpretation of GRACE data using a groundwater recharge model

H. C. Bonsor et al.

Title Page

Abstract

Introduction

Conclusions

References

Tables

Figures

14

$\rightarrow$

4

Back

Close

Full Screen / Esc

Printer-friendly Version

Interactive Discussion 


\section{Abstract}

Assessing and quantifying natural water storage is becoming increasingly important as nations develop strategies for economic growth and adaptations measures for climate change. The Gravity Recovery and Climate Experiment (GRACE) data provide a new 5 opportunity to gain a direct and independent measure of water mass variations on a regional scale. Hydrological models are required to interpret these mass variations and partition them between different parts of the hydrological cycle, but groundwater storage has generally been poorly constrained by such models. This study focused on the Nile basin, and used a groundwater recharge model ZOODRM (Zoomable Ob10 ject Oriented Distributed Recharge Model) to help interpret the seasonal variation in terrestrial water storage indicated by GRACE. The recharge model was constructed using almost entirely remotely sensed input data and calibrated to observed hydrological data from the Nile. GRACE data for the Nile Basin indicates an annual terrestrial water storage of approximately $200 \mathrm{~km}^{3}$ : water input is from rainfall, and much of this water is evaporated within the basin since average annual outflow of the Nile is less than $30 \mathrm{~km}^{3}$. Total annual recharge simulated by ZOODRM is $400 \mathrm{~km} / \mathrm{yr} ; 0-50 \mathrm{~mm} / \mathrm{yr}$ within the semi arid lower catchments, and a mean of $250 \mathrm{~mm} / \mathrm{yr}$ in the sub-tropical upper catchments. These results are comparable to the few site specific studies of recharge in the basin. Accounting for year-round discharge of groundwater, the sea20 sonal groundwater storage is $100-150 \mathrm{~km}^{3} / \mathrm{yr}$ and seasonal change in soil moisture, $30 \mathrm{~km}^{3} / \mathrm{yr}$. Together, they account for between 50 and $90 \%$ of the annual water storage in the catchment. The annual water mass variation $\left(200 \mathrm{~km}^{3} / \mathrm{yr}\right)$ is an order of magnitude smaller than the rainfall input into the catchment $\left(2000 \mathrm{~km}^{3} / \mathrm{yr}\right)$, which could be consistent with a high degree of moisture recycling within the basin. Future work is timing of runoff routing.

HESSD

$7,4501-4533,2010$

Interpretation of GRACE data using a groundwater recharge model

H. C. Bonsor et al.

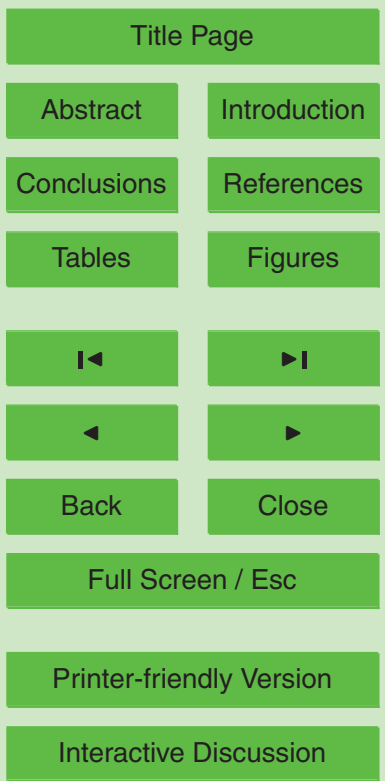




\section{Introduction}

Water storage is a driver for economic growth, poverty reduction and a key component of a nation's resilience to climate change (Grey and Sadoff, 2007; DFID, 2010). For many people in the world, accessing stored water means using groundwater rather 5 than building dams and reservoirs (MacDonald and Calow, 2009). Therefore, as rainfall and surface water resources become less reliable with predicted climate change, being able to assess the spatial distribution and seasonal variation of stored water masses and in particular impacts on groundwater recharge - is increasingly important (Bates et al., 2007; MacDonald et al., 2009). Following the early demonstration that the Gravity 10 Recovery and Climate Experiment (GRACE) satellites were able to detect hydrologically induced gravity changes (Tapley et al., 2004), GRACE data has become a widely used tool for gaining an insight to regional scale water mass variations (e.g. Anderson and Hinderer, 2005; Brown and Tregoning, 2010). Processed GRACE data, corrected for atmospheric and oceanic water variations, give an independent estimate of the total monthly change in terrestrial water storage within a region. The GRACE data is an estimate of bulk water storage changes, and the data cannot distinguish between the different components of stored water mass (Rodell et al., 2004; Schmidt et al., 2006). GRACE data must, therefore, be interpreted using hydrological modelling. Despite this limitation, GRACE data remains a highly valuable dataset as an independent measure of large-scale, bulk water storage variations.

GRACE data have been used successfully to assist basinal-scale water balance calculations (e.g. Rodell et al., 2004; Syed et al., 2005), and to quantify water mass storage changes (e.g. Rodell et al., 2009). To date, most published work interpreting GRACE data has been in regions where there are large mass storage changes related, predominantly, to a single stored water mass (e.g. the major river basins (Schmidt et al., 2006); regions of groundwater depletion in India (Rodell et al., 2009)). Bulk water balance models (e.g. the World Global Hydrological Model WGHM (Döll et al., 2003)) have been widely used to interpret the mass storage changes indicated in GRACE
HESSD

$7,4501-4533,2010$

Interpretation of GRACE data using a groundwater recharge model

H. C. Bonsor et al.

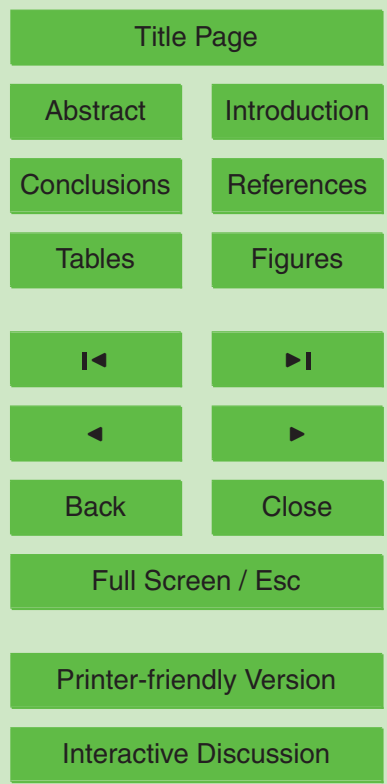


quantitatively, with respect to the regional hydrological cycle. These bulk water balance models use climatic and land-use data to calculate the volume of rainfall, evaporated water and surface runoff within any given catchment. However, the models are unable to accurately model each component of terrestrial water storage. Soil moisture and 5 groundwater are often simply calculated as a "remainder" in the water balance models, leading to the conclusion that a major limitation of the models is their inability to model changes in groundwater storage (Schmidt et al., 2006). As a result, most work to date has not harnessed the full potential of GRACE data to interpret changes in groundwater storage on a basinal scale. Being able to use GRACE data with hydrological models 10 that can simulate all components of terrestrial water storage, particularly groundwater storage, would therefore be of significant value.

To interpret how seasonal water storage variations indicated in GRACE data relate to changes in each component of water storage in a basin, requires the use of hydrological models that are capable of simulating the processes which lead to the partitioning 15 of precipitation between evaporative losses, surface run-off, soil moisture and groundwater recharge on a basin-scale. Rainfall-runoff models (e.g. Beven, 2002) and bulk water balance models concentrate on surface processes with a limited emphasis on soil processes. For these models, recharge is only a "by-product" of moving water around the system, whereas recharge models are specifically designed to simulate soil processes, especially the calculation of actual evaporation. Therefore, they are more appropriate tools to accurately simulate the variation of each component of terrestrial water storage. Using recharge models it should therefore be possible to relate seasonal changes in different stored water masses to the bulk seasonal water storage change indicated by GRACE data.

25 This study develops a recharge model for the Nile Basin, using the ZOODRM code (Hughes et al., 2008), and almost entirely remotely sensed input data. This recharge model is calibrated to observed hydrological data from the Nile, and then used to interpret the seasonal variation in terrestrial water storage indicated by GRACE data from the Nile Basin. Of prime interest in this study is the quantification of the proportion of

\section{HESSD}

$7,4501-4533,2010$

Interpretation of GRACE data using a groundwater recharge model

H. C. Bonsor et al.

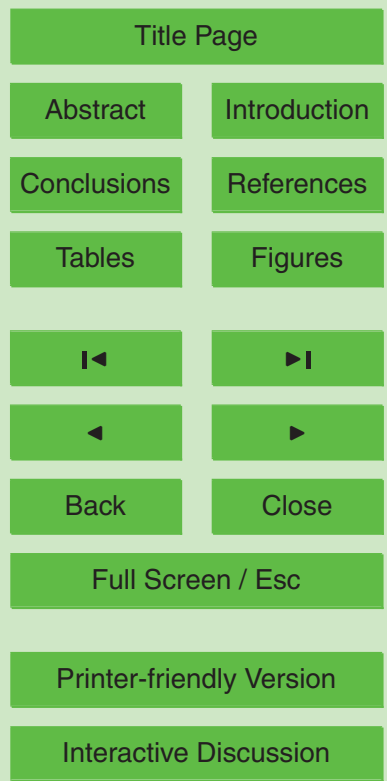


the seasonal GRACE gravity mass variation in the Nile Basin that relates to groundwater recharge and soil moisture changes.

\section{The Nile Basin}

\subsection{The Nile Catchment}

5 Approximately 3 million $\mathrm{km}^{2}$ in extent, the Nile River Basin drains almost $10 \%$ of Africa and includes over 10 countries (Sutcliffe and Park, 1999; Nicol, 2003). The distribution of water resources in the Nile Basin is highly contentious, and water allocations between neighbouring countries in the Nile Basin have historically been the cause of much dispute (Nicol, 2003). The allocation of the Nile flow between the 10 countries in 10 the basin has, traditionally, been done solely on the basis of the proportion of annual surface water availability in each country. Controversy has arisen from this division of the Nile flows as a result of the large difference in climate and seasonal water availability between the upper and lower Nile catchment, and also as a result of the importance of the water to livelihoods and industry within each of the countries (Conway, 2005).

Within Egypt, and much of Sudan, in the arid and semi-arid part of the catchment, the Nile River is the main source of water (Nicol, 2003). Division of the Nile River flows is therefore incredibly important to these countries, not only for drinking and domestic water needs, but for industry and economic growth (Karyabwite, 2000; Conway, 2005). Within the sub-tropical upstream catchment of the Nile Basin, seasonal rainfall somewhat reduces water pressures in Southern Sudan, northeast Congo and south-west Ethiopia (Sutcliffe and Park, 1999). However, water pressures can still be high in these countries within the upstream catchment during the dry season.

More recently, there is growing interest in the total volume of water in each country, rather than the single focus on Nile flows (Karyabwite, 2000; DFID, 2010). Being able to determine terrestrial water stores - such as groundwater - is therefore becoming increasingly important to water resource management in the Nile Basin. In the absence
HESSD

7, 4501-4533, 2010

Interpretation of GRACE data using a groundwater recharge model

H. C. Bonsor et al.

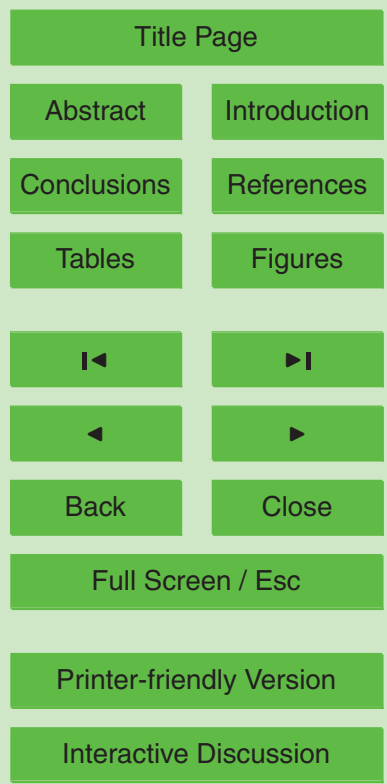


of hydrological data, or difficulty in obtaining such data, the ability to use remotely sensed data to develop accurate, independent hydrological models that can quantify seasonal distributions of stored water mass in a basin, is potentially very important for water resource management in the Nile (Brunner et al., 2007; Mileham et al., 2008;

5 Abdalla, 2009). It is, therefore, in large transboundary basins, such as the Nile, that GRACE data can have highest impact potential as an independent measure of bulk terrestrial water storage variations.

\subsection{Hydrology of the Nile Basin}

The hydrology of the Nile Basin is complex. The hydrology of any particular reach is directly influenced by the adjacent landuse (e.g. irrigation abstraction) and the hydrological regime of major tributaries (Sutcliffe and Park, 1999).

The Nile River extends from the head waters of Lake Victoria and Lake Albert in Uganda and the Democratic Republic of the Congo, to the Mediterranean Sea - Fig. 1. Annual outflow to the Mediterranean is approximately $28 \mathrm{~km}^{3} / \mathrm{yr}$. The basin is divided 15 into a number of sub-catchments: the Victoria Nile, Sudd, White Nile, Sobat, Blue Nile and the Main Nile - Fig. 1. The contribution of each of these sub-catchments to the Main Nile flow is markedly different. Whilst the Victoria Nile and White Nile, provide a constant annual baseflow to the Main Nile of approximately $60 \mathrm{~km}^{3} / \mathrm{yr}$, as much as $70 \%$ of the annual discharge of the Main Nile is sourced seasonally from the Blue Nile,

20 Sobat and Atbara tributaries which originate in the Ethiopian Highlands (Sutcliffe and Park, 1999). These tributaries respond relatively rapidly to the wet season rainfall in the Ethiopian Highlands and provide a seasonal pulse of water to the Main Nile River in the lower catchment. This seasonal response is not observed within the White Nile, because as much as half of the inflow from the Victoria Nile and Bahr el Ghazel sub25 catchments is lost to evaporation within the Sudd wetland (Sutcliffe and Park, 1999) Fig. 1.

Evaporative losses of water throughout the Nile catchment, from both open water evaporation and evapotranspiration, are known to be highly significant to the hydrology 4506

\section{HESSD}

$7,4501-4533,2010$

Interpretation of GRACE data using a groundwater recharge model

H. C. Bonsor et al.

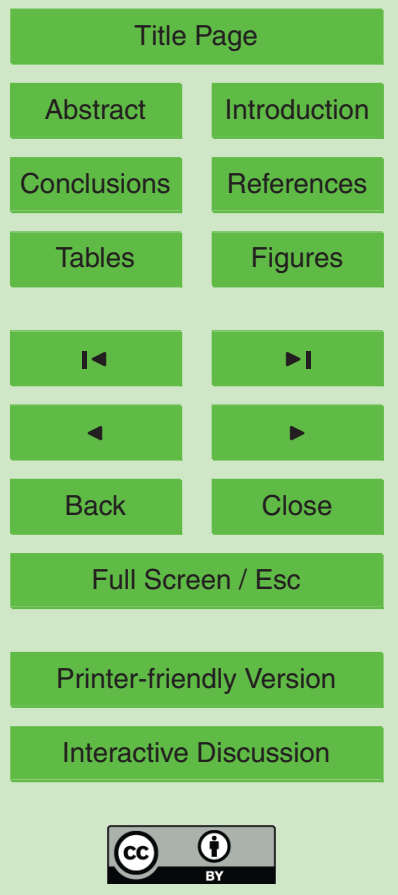


of the Nile, and are evident by the reduction in flow down the Nile (Sutcliffe and Park, 1999). In Sudan and Egypt, in the arid part of the catchment, open water evaporative losses are 1700-2400 mm/yr, and the discharge of the Nile River actually decreases downstream as a result of evaporation (Mohamed et al., 2004; Sutcliffe, 2005; Vallet5 Coulomb et al., 2001; Sutcliffe and Park, 1999) - Fig. 1.

\section{Nile GRACE data}

The satellite mission Gravity Recovery and Climate Experiment (GRACE) has provided independent monthly models of the Earth's gravity field since 2002 (Tapley et al., 2004). GRACE lacks spatial resolution better than a few hundred kilometres (spherical 10 harmonic degree $\sim 50$ ) but, when averaged over regions of this size, it detects consistent mass changes equivalent to the effect of a few millimetres of water (Bedada, 2007). Gravity changes due to short period geological events, like volcanic eruptions or earthquakes, are detectable in extreme cases but produce a step-like change preceded and followed by a slow build-up or recovery (Han et al., 2006). Processes in the 15 hydrosphere, atmosphere and cryosphere are believed to be the only ones capable of generating the mass changes with the seasonal timescale observed in the variability of the gravity field. Month to month changes seen in the gravity field over a low latitude continental region correspond to changes in all sources of sub-satellite water, integrated over the whole vertical column including aquifers, flooding and surface water, rainfall and other moisture in the atmosphere.

For this study of the hydrology of the Nile Basin, GRACE-2 gravity data have been synthesised from the CNES model (Lemoine et al., 2007; Bruinsma et al., 2010), although we have made comparisons with other models generated by groups in the Texas Centre for Space Research, the Geoforschungszentrum in Potsdam and the Jet orbit data with a background gravity model (EIGEN-GRACE-02S) and accelerometer and attitude data, to generate stable solutions of gravity data which are corrected for

HESSD

$7,4501-4533,2010$

Interpretation of GRACE data using a groundwater recharge model

H. C. Bonsor et al.

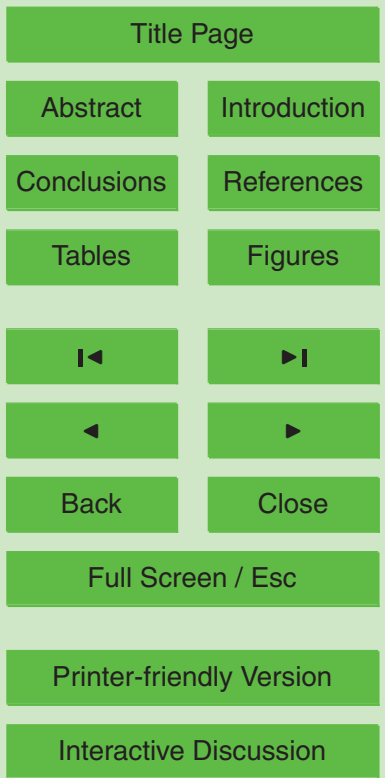


the background solid earth mass variations (Lemoine et al., 2007). The second release of GRACE data from CNES - GRACE-2 - used in this study, have also been corrected for water mass changes occurring within the atmosphere and ocean, using ocean and atmospheric mass variation models (Lemoine et al., 2007). These models simulate oceanic and atmospheric water mass variations, respectively, according to climatic data and tides, and the estimated background variations in water mass variation are subtracted from the total water mass variation indicated by GRACE data in a region. As a result, gravity mass changes indicated by GRACE-2 data, should relate only to monthly changes in terrestrial water storage in the region of interest, plus any 10 error within the GRACE data incurred from the corrections. Based on comparison to gauged meteorological data the error within the Nile Basin, the atmospheric correction is thought to be much less than $20 \mathrm{~mm}$ water equivalent in this region (Bettapdur, personal communication). Note that to predict monthly water mass changes from the GRACE gravity models, time changes of gravity must be identified within GRACE data 15 from an arbitrary datum. This datum is defined by the particular month chosen as reference. In this study March 2004, the driest hydrological month of the modelled period, was used as the reference month.

The Nile GRACE data from 2003 to 2005 indicate a regular seasonal variation of stored water mass in the Nile Basin, equivalent to $\pm 300 \mathrm{~mm}$ water - Fig. 2. Areas of mass addition correspond with the location and timing of the highest seasonal rainfall. Across the Nile Basin, the seasonal change in water mass is approximately $150 \mathrm{~km}^{3}$ (estimated for 2004, Fig. 3).

\section{Comparison of GRACE data with observed hydrological data}

Figure 3 shows a comparison between monthly GRACE data (interpreted as the change in the terrestrial water mass) and observed hydrological data of monthly rainfall and river outflow from the Nile delta. The comparison of GRACE data to observed monthly rainfall confirms that a significant volume of rainfall becomes stored within the

\section{HESSD}

7, 4501-4533, 2010

Interpretation of GRACE data using a groundwater recharge model

H. C. Bonsor et al.

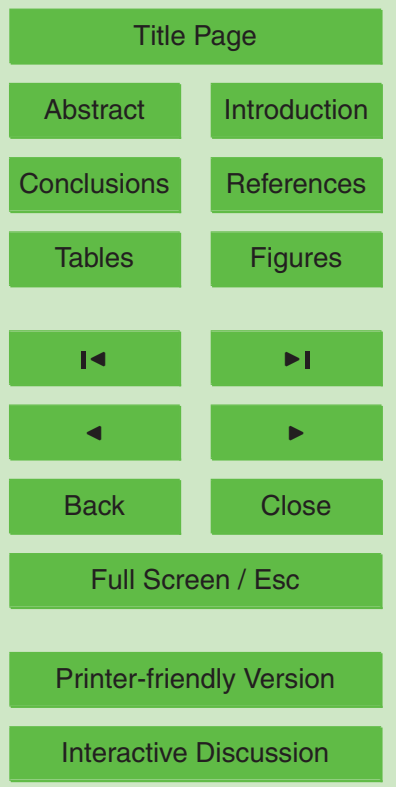


basin. Annual mass change is approximately $150 \mathrm{~km}^{3}$, and total annual rainfall approximately $2000 \mathrm{~km}^{3}$. The small outflow of River Nile, relative to the monthly change in water storage indicated by GRACE, clearly indicates only a very small proportion of the rainfall water becomes stored within the Nile River itself. It is inferred, therefore, 5 that much of the monthly change in water storage indicated by the GRACE data reflects seasonal storage of water in soil moisture, groundwater recharge and, surface lakes and reservoirs. As GRACE data give only a bulk estimate of the change in water storage in the basin, hydrological modelling is required to gain a better understanding of which of these terrestrial water mass stores receive the most rainfall, and how each component of water storage changes seasonally within the basin.

The observed hydrological data also indicate that the annual discharge of the Nile Delta of $28 \mathrm{~km}^{3}$ is less than $2 \%$ of the annual rainfall (approximately $2000 \mathrm{~km}^{3}$ ) input to the basin. This suggests a large volume of the rainfall reaching the ground surface in the Nile Basin is lost through evapotranspiration. This evaporated water could be 15 retained within the atmosphere, lost, or re-precipitated and recycled within the basins hydrological cycle. The magnitude of the correction of GRACE data for atmospheric water in the latest release of data (the data used in this paper), gives an indication as to which of these possibilities is most likely in the Nile Basin. Corrected GRACE data indicate the monthly change in terrestrial water storage in a region; uncorrected GRACE data (earlier releases of data) indicate the monthly change in total water mass (including atmospheric water). In the Nile Basin, there is, on average, only a $5-10 \%$ difference between the corrected and uncorrected GRACE data. This suggests that there is not a significant input of atmospheric water to the Nile Basin. It appears, therefore, that most of the atmospheric water within the Nile Basin is derived from local uncorrected GRACE data indicates the monthly change in atmospheric water is not significant compared to other water stores, suggesting that much of the evaporated water must re-precipitate within the basin, rather than moving in or out of the basin.
HESSD

7, 4501-4533, 2010

\section{Interpretation of GRACE data using a groundwater recharge model}

H. C. Bonsor et al.

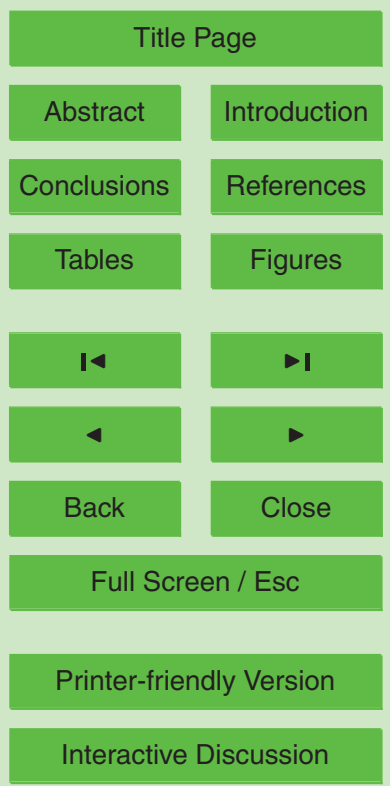


The ECMWF correction of GRACE data is believed to be accurate to well within $20 \mathrm{~mm}$ water equivalent in the Nile Basin on the basis of the comparison between the modelled atmospheric data to which the GRACE data is corrected, and observed meteorological data (Bettadpur, personal communication). The inference that most 5 of the atmospheric water within the Nile Basin is derived from local evaporation is supported by work by Fontaine et al. (2002) in West Africa basins. Comparing detailed atmospheric modelling to gauged meteorological data, Fontaine et al. (2002), infer that much of the atmospheric water in the West African basins is derived from local evaporation.

10 Comparing the Nile GRACE data to observed hydrological data is a useful exercise and clearly indicates that: (1) up to $10 \%$ of rainfall in the catchment becomes stored within the basin; (2) little water is stored within the River Nile, and therefore, a significant amount of rainfall must become stored within other terrestrial water stores - namely, soil moisture, groundwater recharge, and surface water bodies; (3) evaporative losses are large within the Nile Basin, and a significant amount of the atmospheric water within the Nile Basin is sourced from local evaporation; and (4) much of the evaporated water is re-precipitated within the basin. GRACE data does not distinguish where water mass is stored in a basin. To be able to interpret which component of terrestrial water storage is most significant in the Nile Basin, therefore, requires the use of groundwater

\section{ZOODRM groundwater recharge model}

\subsection{The ZOODRM model}

The ZOODRM model is a distributed recharge model code for calculating spatial and temporal variations in groundwater recharge, and has been applied successfully in semi-arid areas (e.g. Palestine-Hughes et al., 2008 and Inner Mongolia - Ó Dochartaigh et al., 2010) and in wet temperate areas (e.g. Europe - Jackson et al., 2005).

HESSD

$7,4501-4533,2010$

Interpretation of GRACE data using a groundwater recharge model

H. C. Bonsor et al.

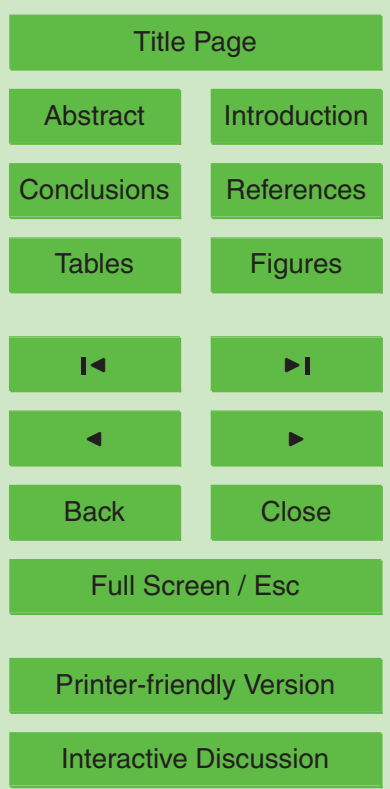

\section{0}


ZOODRM calculates recharge by applying the soil moisture deficit (SMD) recharge method over daily time steps (Penman, 1948; Grindley, 1967). The SMD method determines how the actual evaporation $(\mathrm{AE})$ is related to the potential evaporation (PE) by the amount of water stored in the soil at any time. Using a daily time step, rainfall less 5 runoff, is added to the soil store and the appropriate evaporation is taken off. When the SMD is between zero and a value know as the root constant $(C)$ then $A E$ is equal to PE. However, once the SMD is greater than the root constant, but less than the wilting point $(D)$ then AE is a proportion (usually 10\%) of PE. Once the SMD is above the wilting point then no further evaporation occurs as the plant is deemed stressed and 10 can no longer transpire. This method allows the impact of water available in the soil on the effects of plant water uptake to be assessed. Separate objects are used to represent different entities within the ZOODRM code such as soil, rivers and springs. These nodes are, in turn, held in a two layer grid structure comprised of an unsaturated and saturated grid. The ZOODRM model is therefore able to represent the numerous flow processes controlling the partitioning of surface water and groundwater, as well as the delay time required for water in the unsaturated zone to reach the water table (Hughes et al., 2008). ZOODRM is also able to simulate evaporative losses from open water surfaces, such as the Sudd wetland, which are known to be important to the hydrology of the Nile Basin (Sutcliffe and Park, 1999). ZOODRM outputs monthly estimates of rainfall, evapotranspiration (ET), change in soil moisture, groundwater recharge, surface runoff and river discharge.

Lerner et al. (1990) suggest that the SMD method can be used where the input to the system, i.e. precipitation and irrigation returns, is greater than $500 \mathrm{~mm} / \mathrm{a}$. This condition is reached, on average, for the Nile basin. However due to the spatial distribution of 25 rainfall, the condition is not met in the arid northern subcatchments. Here, rainfall and recharge is negligible and accounts for little of the overall Nile Basin mass balance. Therefore, a pragmatic approach was taken to apply the SMD over the whole basin with the provision that the model does not produce anomalous results in the arid north (and therefore affect the mass balance of the basin).

\section{HESSD}

$7,4501-4533,2010$

Interpretation of GRACE data using a groundwater recharge model

H. C. Bonsor et al.

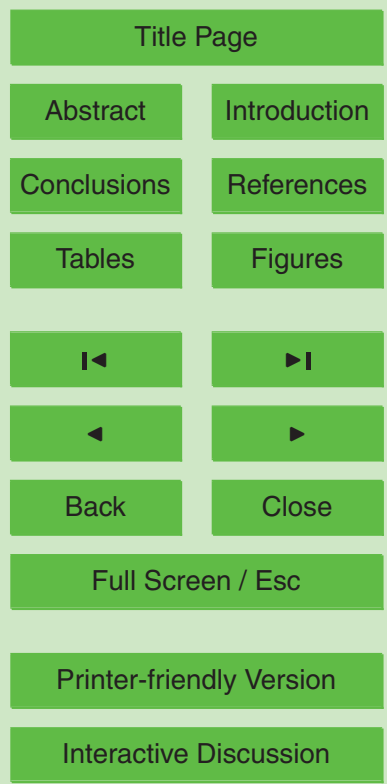


The ZOODRM model is a suitable model for this study due to its lower data demands relative to other hydrological models, the ability of the model to use largely remotely sensed data, and, the added functionality of routing of runoff water according to topography. The data needs of the model are: daily rainfall and potential evaporation (PE), 5 land use, topographical aspect directions, geological and digital elevation data. Due to the size of the Nile Basin and difficulties in obtaining recorded rainfall and evaporation data from individual countries, largely remotely sensed input data were used for the modelling work. Daily rainfall (NOAA data) and PE were sourced from the FEWS NET African Dissemination Service for 2003-2005. Geological data were sourced from the 10 Digital Geological Map of the World (UNESCO, 1991; Persits, 1997), land-use data from the USGS (http://edc2.usgs.gov/glcc/glcc.php; Loveland et al., 2000) and elevation data from the Shuttle Mission (STRM) (http://www2.jpl.nasa.gov/srtm/; Farr et al., 2007).

A $20 \times 20 \mathrm{~km}$ cell size was adopted for the model grid as a compromise between 15 model accuracy and model run time. This model resolution, although coarse, is greater than that achieved by previous basin-scale modelling work in the Nile (e.g. Mohamed et al., 2005, whose modelling work was of $50 \times 50 \mathrm{~km}$ resolution), and by other hydrological models used with GRACE data (e.g. Fukuda et al., 2009). All input data were gridded to be of the same $20 \mathrm{~km}^{2}$ resolution and projected to a UTM zone 36 projection to ensure no error was introduced into the ZOODRM model when input data files were read. This projection of input data was required to ensure minimal scalar, or areal distortion of the data within the modelled area. Preservation of area within the model is important to model accuracy, as the ZOODRM model integrates water fluxes over area. Due to the size of the Nile Basin, the curvature of the Earth would induce jections. Surface routing of runoff water is calculated according to a slope aspect map generated from digital elevation model data (DEM). The aspect direction at any grid point determines the direction of movement of surface runoff, which is generated as a proportion of the effective precipitation plus any water received from an adjacent cell.
HESSD

$7,4501-4533,2010$

Interpretation of GRACE data using a groundwater recharge model

H. C. Bonsor et al.

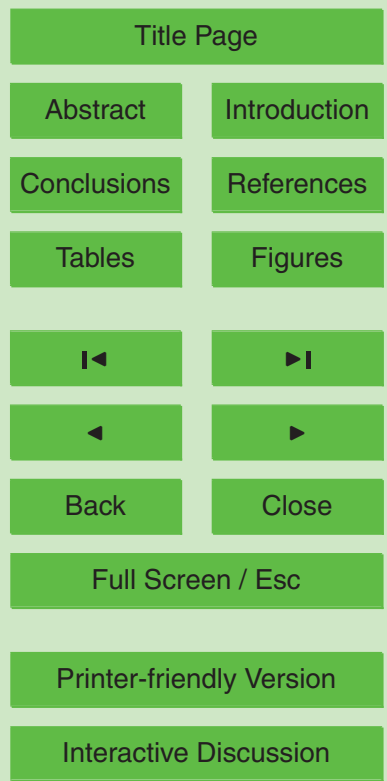


The recharge model has a simplified method of calculating run-off routing based on a time step of one day (Hughes et al., 2008). Currently this is fixed and is adequate for small sub-catchments. It is recognised that the timing of run-off would be greatly improved by allowing a variable timing and this would be a further refinement of the Nile 5 basin model. Calculation of recharge according to the soil moisture deficit method, relies on the root constant $(C)$ and wilting point $(D)$ values which are characteristics of the vegetation type. For the different vegetation types within the Nile Basin, $C$ and $D$ values were obtained from published values (see FAO; Lerner et al., 1990). Other modelling factors were kept as simple as possible in this preliminary stage of model de-

10 velopment. Irrigation losses were set to zero to ensure that it was only the partitioning of surface water to run-off and recharge which determined the modelled river discharge and groundwater water mass. Open water evaporation rates from the Sudd wetland, and the Nile river surface were modelled as 3-7 mm/day according to published values (e.g. Sutcliffe, 2005; Mohamed et al., 2004).

\subsection{Model calibration}

The ZOODRM model was run for three full hydrological years from 2003 to 2005, and calibrated to observed annual discharge from 1976-1979 (no modern data available) at 10 gauging stations along the Main Nile and tributaries. No modern discharge data is available from the Nile Basin beyond 1979, bar two gauging stations on the White Nile 20 and Main Nile. The discharge data from these stations, is very similar to the discharge data from 1976-1979 ( $\pm 14 \%$ difference), indicating the use of discharge data from 1976-1979 is valid in the absence of any other data.

The recharge model simulates observed annual discharge of the Nile River to within $40 \%$ (and in most cases within 20\%), using realistic values of run-off (modelled to 25 vary seasonally between $10-27 \%$ of rainfall), overland losses ( $2 \%$ of run-off) and river losses (0-3\% river discharge) - Table 1 . These modelled values of run-off are comparable to other published estimates (e.g. Mohamed et al. (2005), who used runoff values of $5-29 \%$ rainfall). It was deemed valid to include overland losses (simulated by the

\section{HESSD}

$7,4501-4533,2010$

Interpretation of GRACE data using a groundwater recharge model

H. C. Bonsor et al.

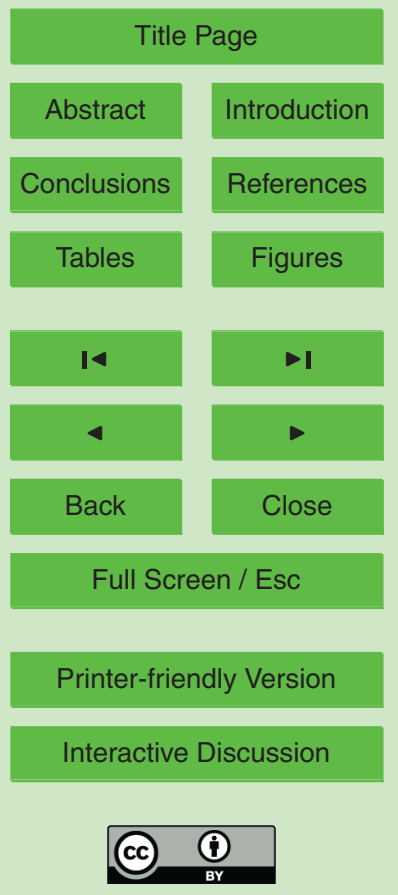


RunOn parameter within the recharge model) due to the semi-arid nature of the lower catchment and overland losses have proved to be important to previous ZOODRM models within semi-arid areas (e.g. Hughes et al., 2008). The overland losses (modelled as $2 \%$ of run-off) were calibrated according to comparison of the modelled dis5 charge against the observed data available.

Greatest error between observed and modelled river discharge occurs in the simulation of river flow within the Sudd wetland at Bahr el Jebel, in the upper catchment (modelled river flow is $43 \%$ greater than observed). Elsewhere, the model simulates observed annual discharge to within $20 \%$. Based on this comparison of modelled and 10 observed annualised discharge in the Nile Basin, it is inferred that the ZOODRM model simulates the discharge of the Nile River and consequently the wider hydrological functioning of the Nile Basin to an acceptable level of accuracy. The water balance of the model, in which no long-term, inter-annual, gain or loss of water is modelled in the basin, also indicates the model is replicating the observed hydrological functioning of the Nile Basin accurately. It is known that there are no large-scale abstractions of water in the Nile Basin (irrigation abstractions being of relatively low intensity compared with other countries worldwide), or major changes in rainfall (Sutcliffe and Park, 1999). GRACE data also do not indicate a long-term interannual change to the total water mass within the basin between 2003 and 2005. However, undoubtedly, a better calibration of the ZOODRM model would be facilitated by access to modern discharge data.

\subsection{Modelling results}

The ZOODRM model simulates the partitioning of the observed rainfall mass between other components of the water cycle in the river basin, and calculates the daily quan-

tities of evapotranspiration (ET), runoff, river outflow and groundwater recharge in the Nile Basin throughout each hydrological year from 2003-2005. Simulated monthly volumetric estimates of ET, runoff, river outflow and groundwater recharge in the Nile are displayed in Fig. 4. The modelling results replicate both observed data, and the known 4514
HESSD

$7,4501-4533,2010$

Interpretation of GRACE data using a groundwater recharge model

H. C. Bonsor et al.

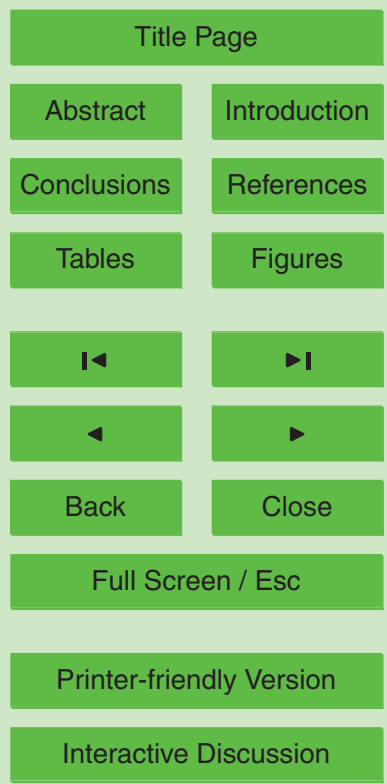

Interactive Discussion 
hydrological functioning of the Nile Basin within acceptable limit of error (i.e. plausible runoff, recharge and evaporation are modelled). This indicates that at a basic level the recharge model simulates the key hydrological processes in the Nile Basin sufficiently well so that the modelled functioning of the Nile Basin matches the observed 5 data available.

Modelling results confirm that river outflow from the basin is only $1.5-2 \%$ of the observed rainfall, and consequently, the Nile River accounts for only a very small amount of the water stored within the Nile Basin. This inference is supported by the comparison of GRACE data to observed hydrological data. The volume of water lost from the Nile 10 Basin by river discharge is also small relative to the volume of water evaporated within the basin; the annual outflow of the Nile River being less than $15 \%$ of the evaporated water mass.

Modelling results indicate evaporative losses to be very large within the Nile Basin. The large difference between the initial volume of surface runoff generated by rainfall, 15 and the annual discharge of the Nile River, suggests a large proportion of runoff water becomes evaporated $\left(\sim 8 \mathrm{~km}^{3} / \mathrm{yr}\right)$.

A significant volume of rainfall is modelled to become stored as groundwater. Groundwater recharge is modelled to be greatest within the Ethiopian and Sudanese Highlands and northeast Congo, corresponding to the areas of highest rainfall in the Nile Basin - Fig. 5. High recharge is also observed within $20 \mathrm{~km}$ of the Nile River due to direct recharge through the river bed - river losses were modelled to be 0$3 \%$ depending on geology and based on river losses estimated from isotope studies (e.g. Abdalla, 2009). Within the semi-arid lower catchment average annual recharge is modelled to be $0-50 \mathrm{~mm} / \mathrm{yr}$, whilst in the sub-tropical upper catchment modelled 25 recharge is on average $250 \mathrm{~mm} / \mathrm{yr}$. The total annual groundwater recharge simulated by ZOODRM is $400 \mathrm{~km}^{3} / \mathrm{yr}$, which is considerably greater than river outflow from the Nile Basin. This estimate is comparable to other larger scale recharge estimates in Africa by Döll and Fiedler (2008) who calculate $0-200 \mathrm{~mm} / \mathrm{yr}$ of recharge in the Nile Basin on a 0.5 degree grid, equivalent to $50 \times 50 \mathrm{~km}$ resolution. The recharge estimate
HESSD

$7,4501-4533,2010$

Interpretation of GRACE data using a groundwater recharge model

H. C. Bonsor et al.

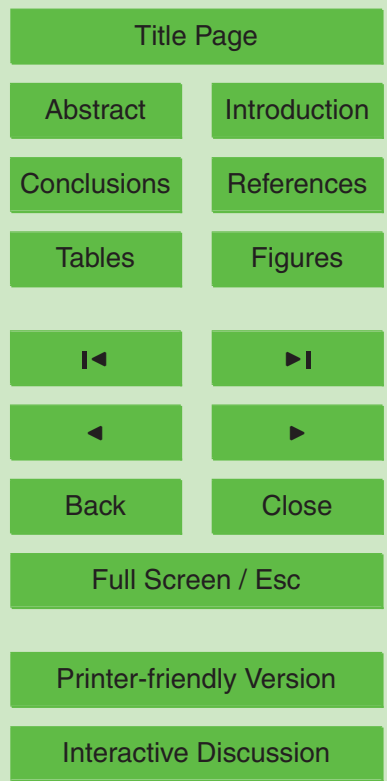


is also comparable to those from smaller regional studies in the Nile which use isotope and chloride concentrations as indicators of groundwater recharge and discharge - Fig. 5. Taylor and Howard (1996) determined annual groundwater recharge in the Aroca catchment of the Victoria Nile, in central Uganda, to be $\sim 200 \mathrm{~mm} / \mathrm{yr}$, using a soil 5 moisture balance model and isotope data. The modelled recharge value for the same region by this work is $\sim 150-200 \mathrm{~mm} / \mathrm{yr}$. MacDonald et al. (2009) determined groundwater recharge in the Singida region of northern Tanzania to be $10-50 \mathrm{~mm} / \mathrm{yr}$, which is within $20 \%$ of the recharge modelled by this work. Within southern Sudan, Abdalla et al. (2009) determined recharge from direct infiltration of rainfall through the soil to be 10 less than $10 \mathrm{~mm} / \mathrm{yr}$ at distances $20-30 \mathrm{~km}$ away from the Nile River. Recharge values modelled for the same region by the ZOODRM model are $0-50 \mathrm{~mm} / \mathrm{yr}$. Finally, within northeast Sudan, Farah et al. (1999) determined the contribution of modern rainfall to groundwater recharge, near the capital city, Khartoum, to be minimal. This inference is supported by the results of this modelling work, which estimates $0-50 \mathrm{~mm} / \mathrm{yr}$ of modern 15 recharge at Khartoum, with values of more than $40 \mathrm{~mm}$ annual recharge being atypical.

\section{Discussion}

\subsection{Moisture recycling in the Nile Basin}

This section discusses the relationship of GRACE data to moisture recycling resulting from the cycling of rainfall and evaporation in the same catchment. GRACE data indicate an average seasonal water mass change of approximately $200 \mathrm{~km}^{3}$ within the Nile Basin each year; annual rainfall is approximately an order of magnitude greater, $2000 \mathrm{~km}^{3}$. Therefore, $90 \%$ of rainfall is not retained, but is lost either through the Nile into the Mediterranean Sea, or to the atmosphere through evapotranspiration. Since average annual Nile flow at the Mediterranean is only $28 \mathrm{~km}^{3}$, virtually all the terrestrial
HESSD

$7,4501-4533,2010$

Interpretation of GRACE data using a groundwater recharge model

H. C. Bonsor et al.

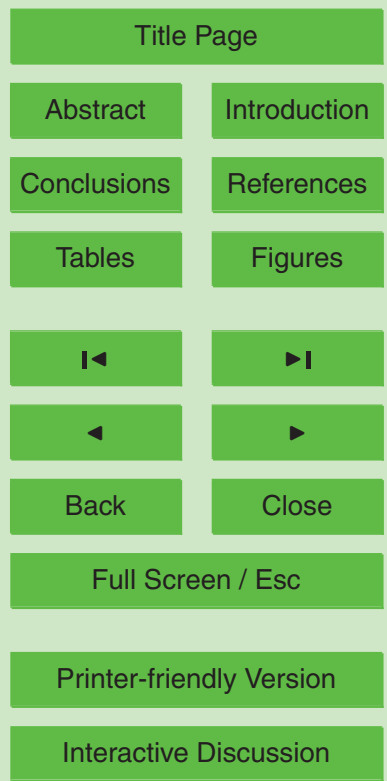


However, annual changes in atmospheric water volumes are inferred to be less than $10 \%$ of the total annual water change by the comparison of corrected and uncorrected GRACE data using the ECMWF model. This suggests that much of this evaporated water of is rapidly re-precipitated within the basin, rather than the water being held in 5 the atmosphere. This is in contrast to the work of Mohamed et al. (2005) who estimated much lower (11\%) moisture recycling within the Nile Basin. However, a similar large influence of moisture recycling within West African river basins was suggested by Fontaine et al. (2002), based on work with atmospheric models and observed meteorological and hydrological data.

\subsection{Groundwater and soil storage}

Groundwater recharge modelled by ZOODRM is a calculation of the total volume of water draining from the soil into the ground. However, assuming a quasi-equilibrium annual water balance in Nile Basin (i.e. no large long-term water deficit or surplus) we can infer there is neither a large net gain or loss of groundwater. This assumption is 15 reasonable for the basin since regional groundwater abstraction is limited. Under this assumption, annual recharge will be approximately matched by an equal volume of groundwater discharge within the Nile Basin. Discharge will occur largely as baseflow to rivers, groundwater abstraction and direct evapotranspiration from shallow groundwater (Farah et al., 1999) and it is likely, therefore, to be relatively constant throughout

the year. We have used the term $\Delta$ groundwater storage to refer to the difference between modelled monthly groundwater recharge and monthly groundwater discharge (which is assumed constant each month and therefore equal to the average monthly groundwater recharge). Using this approach, the seasonal mass change in the Nile Basin due to groundwater is estimated to be $100-150 \mathrm{~km}^{3} / \mathrm{yr}$ for $2003-2005$ (Fig. 6). 25 The seasonal change in groundwater storage accounts for more than $50 \%$ of the annual water mass variation calculated from GRACE data.

Modelled changes in soil moisture throughout the year are approximately $30 \mathrm{~km}^{3}$ and are most significant at the beginning of the rainy season as the soils wet up before
HESSD

$7,4501-4533,2010$

Interpretation of GRACE data using a groundwater recharge model

H. C. Bonsor et al.

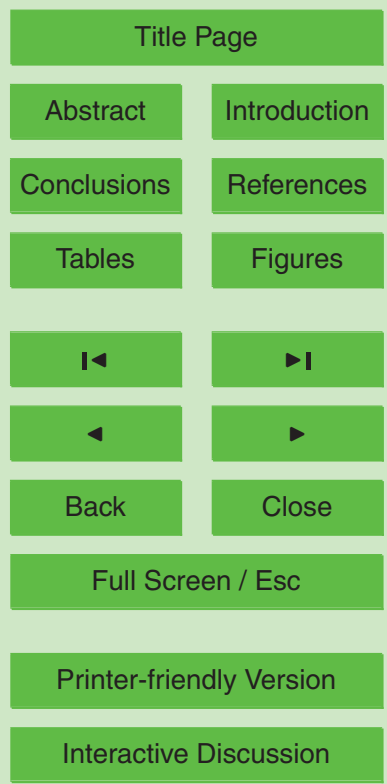

Interactive Discussion 
significant groundwater recharge can occur, and at the beginning of the dry season as the soils dry out.

Taken together, the simulated annual variation in groundwater storage and soil moisture accounts for $50-90 \%$ of the variation in stored water mass indicated by GRACE 5 data in the Nile Basin - Fig. 7; the remainder of water mass is runoff. As a result of the slow river flows, irrigation, and high evapotranspiration rates in the Nile basin, much of the runoff is evaporated within several months rather than flowing out into the Mediterranean. In wetter years (e.g. 2003) there is a much higher runoff, and a greater proportion of storage is not accounted for by groundwater and soil storage - Fig. 7 .

\subsection{Limitations of modelling results}

There are three main limitations to the ZOODRM recharge model for the purposes of this work: (1) ZOODRM simulates run-off to be lost too quickly to the River Nile, and therefore the volume of run-off is generally underestimated by the model; (2) the ZOODRM model underestimates the storage of surface water (lakes, wetlands) and 15 simulates the seasonal variation in this surface water store poorly; and (3) storage of water in artificial reservoirs is excluded from the model.

\section{Simulation of runoff}

As described in Sect. 5.1, ZOODRM uses a fixed time step of one day and routes water down the topographic gradient during the time step. Therefore, there is no delay in rainfall striking the ground surface and reaching the river channel. This means that run-off arrives at and discharges from the river system too quickly. This has implications for the comparison of the water stored in the system that is calculated by the recharge model with the GRACE data. Within particularly wet years (e.g. 2003), when the volume of run-off to the Nile catchments water balance will be more significant, the underestimation of run-off and the resulting surface water storage, is most apparent when the bulk
HESSD

$7,4501-4533,2010$

Interpretation of GRACE data using a groundwater recharge model

H. C. Bonsor et al.

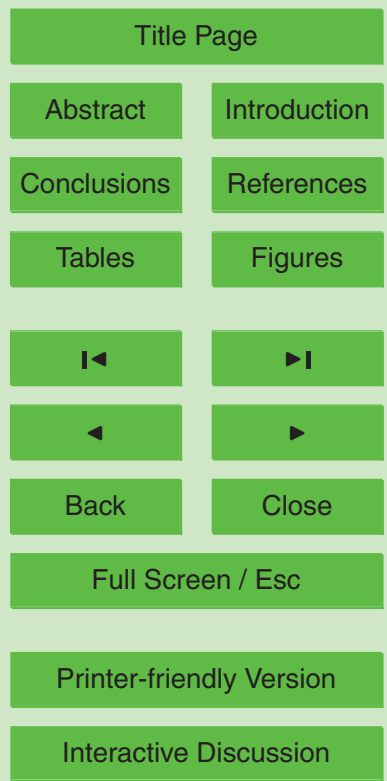


stored water mass modelled in the catchment is compared to GRACE data - Fig. 7. Within drier years (e.g. 2004) when there is less rainfall, and run-off is less significant, the bulk stored water masses modelled by the recharge model compare much better to the annual water storage variation indicated by the GRACE data. This limitation of 5 the model is not, however, thought to incur significant error to the calculation of soil moisture and recharge volumes, as the model calculates theses water masses using the soil moisture deficit approach, and the most significant factors to the calculations the volume of effective precipitation reaching the ground surface, potential evaporation (PE) and land cover - do not rely on the run-off.

10 As a result of the ZOODRM recharge model routing run-off water into the Nile River too quickly, the model underestimates the volume of run-off water which will be evaporated, to be either lost from the basin, or more likely, to be re-precipitated. This modelling limitation is unlikely to be significant to the recharge calculated by the model, but it is important to note as a model limitation.

\subsection{Future work}

This work has shown it is possible to develop a recharge model on a basinal-scale using largely remotely sensed data and to use distributed recharge modelling to interpret subtle, seasonal variations in stored water mass indicated by GRACE data. Using a recharge model it is possible to quantify how significant seasonal variations in the different stored water masses within a large river basin are to the GRACE data. This level of interpretation is not possible using only bulk water balance models.

Building from this initial application of the recharge model to interpret GRACE data, future work is required to advance the calibration of the ZOODRM recharge model, to enable more accurate comparison of modelling results to the GRACE data. Future 25 development of ZOODRM recharge model should:
HESSD

7, 4501-4533, 2010

Interpretation of GRACE data using a groundwater recharge model

H. C. Bonsor et al.

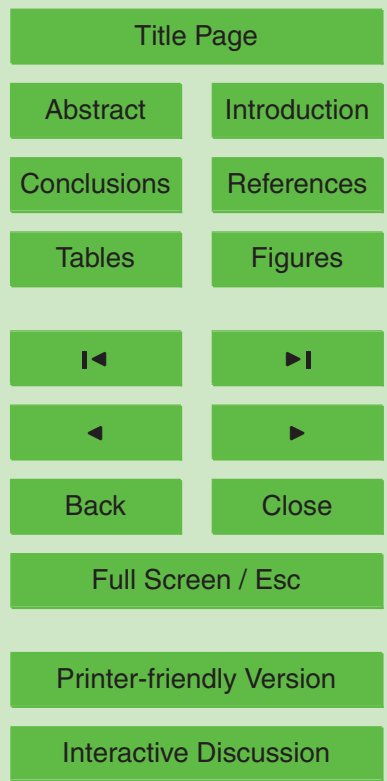


- Enable accurate simulation of run-off routing time of surface water within the recharge model across large distances (at present only annualised flows can be compared);

HESSD

- Enable accurate simulation of stored water mass in surface water bodies,

- Include artificial storage of water in the man-made reservoirs in the recharge model, as well as known irrigation abstraction losses.

A further key need in future work is to calibrate the Nile recharge model to modern discharge data. Obtaining modern discharge data for the Nile River and its tributaries is very difficult in the large transboundary basin where allocation of surface water resources is highly contentious. Techniques for using satellite radar altimetry to determine surface water levels in lakes and rivers are being developed, and their application to the Nile Basin could provide modern estimates of river flows (e.g. Berry and Pinnock, 2003) and improve the level of attainable model calibration. Whilst satellite altimetry techniques would only generate estimated modern discharge data, the data would be independent - a key factor in a large transboundary basin where water resources are under extreme pressure, and hydrological data highly contentious.

\section{Conclusions}

This study developed a groundwater recharge model for the Nile Basin, using the ZOODRM code, and almost entirely remotely sensed input data. The recharge model was calibrated to observed hydrological data from the Nile, and then used to interpret the seasonal variation in terrestrial water storage indicated by GRACE data from the Nile Basin. The results of this work are:

1. GRACE data for the Nile Basin indicates a seasonal spatial variation to gravity of $\pm 0.005 \mathrm{mGal}$ in the basin, which relates to annual change in terrestrial water storage change of approximately $200 \mathrm{~km}^{3}$ : water input is rainfall, and much of this

\section{Interpretation of GRACE data using a groundwater recharge model}

H. C. Bonsor et al.

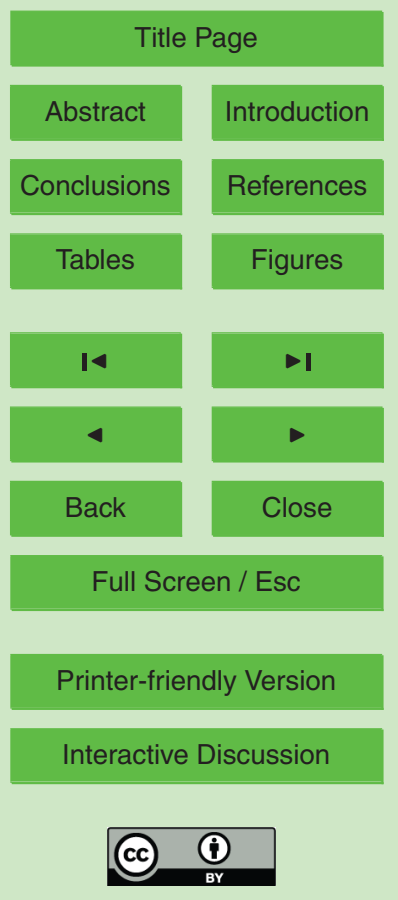


water is evaporated within the basin since average annual outflow of the Nile is less than $30 \mathrm{~km}^{3}$.

2. The total annual groundwater recharge simulated by ZOODRM is $400 \mathrm{~km}^{3} / \mathrm{yr}$ - a figure considerably greater than river outflow from the Nile Basin. Within

The results of this study show the value of using distributed recharge models, over bulk water balance models, to interpret subtle variations in GRACE data. Using a groundwater recharge model it is possible to gain an insight into the partitioning, and seasonal variation, of stored water masses within river basins. In addition, this work has also shown it is possible to develop a plausible, robust, recharge model using

The annual water mass variation $\left(200 \mathrm{~km}^{3} / \mathrm{yr}\right)$ is an order of magnitude smaller than the rainfall input into the catchment $\left(2000 \mathrm{~km}^{3} / \mathrm{yr}\right)$, and river outflow is negligible $\left(<30 \mathrm{~km}^{3} / \mathrm{yr}\right)$. This indicates the high evaporative losses to be significant within the Nile Basin. However, annual changes in atmospheric water volumes are inferred to be less than $10 \%$ of the total annual water change by the comparison of corrected and uncorrected GRACE data using the ECMWF model. This suggests that much of this evaporated water of is rapidly re-precipitated within the basin, rather than the water being held in the atmosphere.
HESSD

$7,4501-4533,2010$

\section{Interpretation of GRACE data using a groundwater recharge model}

H. C. Bonsor et al.

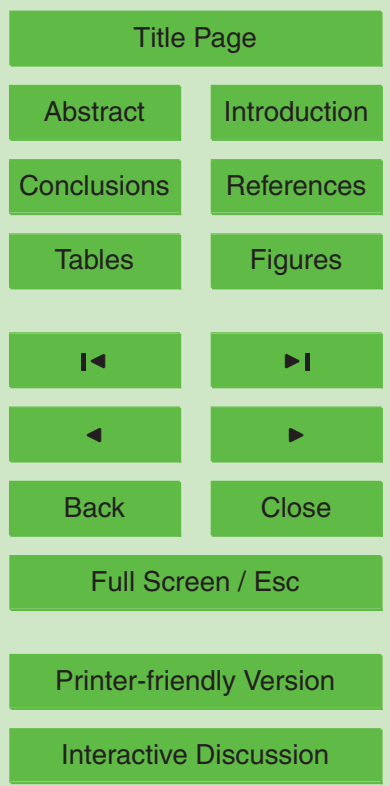


almost entirely remotely sensed input data. Future work is required to advance the calibration of the ZOODRM model, particularly in including a timing element in the run-off routing.

Acknowledgements. This paper is published with permission of the Director of the British Ge5 ological Survey (Natural Environment Research Council).

\section{References}

Abdalla, O. A. E.: Groundwater recharge/discharge in semi-arid regions interpreted from isotope and chloride concentrations in north White Nile Rift, Sudan, Hydrogeol. J., 17, 3, 679692, 2009.

Anderson, O. B. and Hinderer, J.: Global inter-annual gravity changes from GRACE: Early results, Geophys. Res. Lett., 32, 1, L01402, doi:10.1029/2004GL020948, 2005.

Bates, B., Kundzewicz, Z., Wu, S., and Palutikof, J. (Eds.): IPCC: Climate change and water, IPCC Working Group II, Technical Paper of the Intergovernmental Panel on Climate Change, IPCC Secretariat, Geneva, 210 pp., 2007.

15 Bedada, T.: Combining space based GRACE gravity field measurement and climatologically averaged precipitation data to assess essential features of hydrological mass variations within the Nile Basin, MSc Thesis, Addid Ababa University, 2007.

Berry, P. A. and Pinnock, R. A.: The potential contribution of satellite altimetry to retrieval of the global hydrology runoff budget, Geophys. Res. Abstr., 5, abstract no. 04389, EGS-AGU-EUG Joint Assembly, Nice, France, April 2003.

Beven, K. J.: Rainfall-runoff modelling: the primer, John Wiley and Sons, England, 2002.

Brown, N. J. and Tregoning, P.: Quantifying GRACE data contamination effects on hydrological analysis in the Murray-Darling Basin, southeast Australia, Aust. J. Earth. Sci., 57, 3, 329335, 2010.

25 Bruinsma, S., Lemoine, J. M., Biancale, R., et al.: CNES/GRGS 10-day gravity field models (release 2) and their evaluation, Adv. Space Res., 45, 4, 587-601, 2010.

Brunner, P. Hendricks Frannsen, H.-J., Kgotlhang, L., Bauer-Gottwein, P., and Kinzelbach, W.: How can remote sensing contribute in groundwater modelling?, Hydrogeol. J., 15, 5-18, 2007.
HESSD

$7,4501-4533,2010$

Interpretation of

GRACE data using a groundwater recharge model

H. C. Bonsor et al.

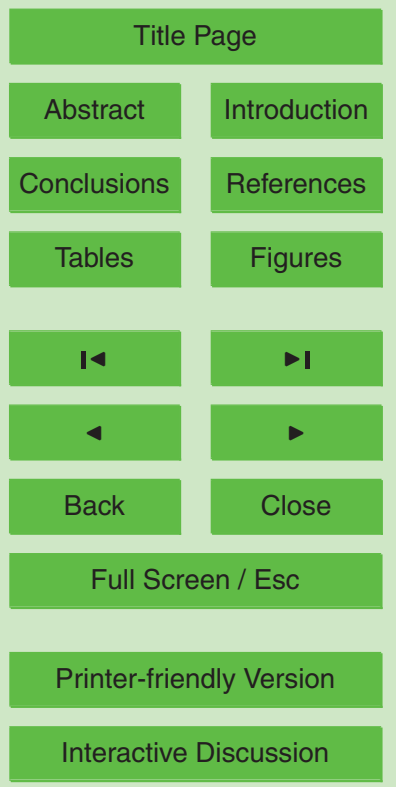


Conway, D.: From headwater tributaries to international river: Observing and adapting to climate variability and change in the Nile Basin, Global Environ. Chang., 15, 99-114, 2005.

DFID: Water Storage and hydropower: supporting growth, resilience and low carbon development, DFID evidence-into-action paper, Department for International Development, UK, $5 \quad$ London, 26 pp., 2010.

Döll, P., Kaspar, F., and Lehner, B.: A global hydrological model for deriving water availability indicators: model tuning and validation, J. Hydrol., 270, 105-134, 2003.

Döll, P. and Fiedler, K.: Global-scale modeling of groundwater recharge, Hydrol. Earth Syst. Sci., 12, 863-885, doi:10.5194/hess-12-863-2008, 2008.

10 FAO: Crop evapotranspiration; Guidelines for computing crop water requirements, Food and Agriculture Organization of the United Nations Irrigation and Drainage Paper 56, Rome, 1998.

Farah, E. A., Mustafa, E. M. A., and Kumai. H.: Sources of groundwater recharge at confluence of the Niles, Sudan, Environ. Geol., 39, 6, 667-672, 1999.

15 Farr, T. G., Rosen, P. A., Caro, E., Crippen, R., et al.: The Shuttle Radar Topography Mission, Rev. Geophys., 45, RG2004, doi:10.1029/2005RG000183, 2007.

Fontaine, B., Roucou, P., and Trzaska, S.: Atmospheric water cycle and moisture fluxes in the West African Monsoon: mean annual cycles and relationship using NCEP/NCAR reanalysis, Geophys. Res. Lett., 30, 3, 1117-1121, 2002.

20 Fukuda, Y., Yamaoto, K., Hasegawa, T., Nakaegawa, T., Nishijima, J., and Taniguchi, M.: Monitoring groundwater variation by satellite and implications for in-situ gravity measurements, Sci. Tot. Environ., 407, 3173-3180, 2009.

Grey, D. and Sadoff, C. W.: Sink or Swim? Water security for growth and development, Water Policy, 9, 545-571, 2007.

25 Grindley, J.: The estimation of soil moisture deficits, Meteorol. Mag., 96, 1137, 97-108, 1967.

Han, S. C., Shum, C. K., Bevis, M., et al.: Crustal dilation observed by GRACE after the 2004 Sumatra-Andaman earthquake, Science, 313, 658-662, 2006.

Hughes, A. G., Mansour, M. M., and Robins, N.: Evaluation of distributed recharge in an upland semi-arid karst system: the West Bank Mountain Aquifer, Middle East, Hydrogeol. J., 16, 5, 845-854, 2008.

Jackson, C. R., Hughes, A. G., Ó Dochartaigh, B. E., Robins, N. S., and Peach D. W.: Numerical testing of conceptual models of groundwater flow: A case study using the Dumfries Basin Aquifer, Scot. J. Geol., 41(1), 51-60, 2005.
HESSD

$7,4501-4533,2010$

Interpretation of

GRACE data using a groundwater recharge model

H. C. Bonsor et al.

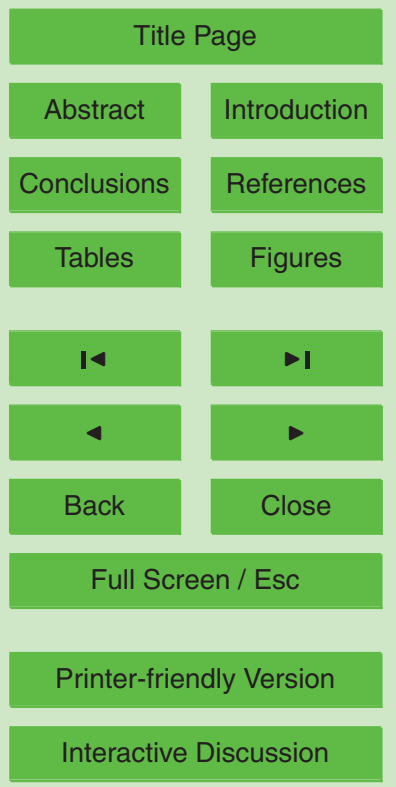


Karyabwite, D. R.: Water sharing in the Nile River Valley, UNEP/DEWA/GRID, Geneva, Project GNV011: Using remote sensing for the sustainable use of natural resources, 2000.

Lemonie, J.-M., Bruinsma, S., Loyer, S., Biancale, R., Marty, J.-C., Perosanz, F., and Balmino, G.: Temporal gravity field models inferred from GRACE data, Adv. Space Res., 39, 16201629, 2007.

Lerner, D. N., Issar, A. S., and Simmers, I.: Groundwater recharge: a Guide to understanding and estimating natural recharge, IAH Publication, No. 8, 1990.

Loveland, T. R., Reed, B. C., Brown, J. F., Ohlen, D. O., Zhu, J., Yang, L., and Merchant, J. W.: Development of a Global Land Cover Characteristics Database and IGBP DISCover from 1-km AVHRR Data., Int. J. Remote. Sens., 21, 6-7, 1303-1330, 2000.

MacDonald, A. M. and Calow, R. C.: Developing groundwater for secure water supplies in Africa, Desalination, 248, 546-556, 2009.

MacDonald, A. M., Calow, R. C., Macdonald, D. M. J., Darling, W. G., Ó Dochartaigh, B. É.: What Impact will climate change have on rural water supplies in Africa?, Hydrolog. Sci. J., 15 54, 690-703, 2009.

MacDonald, A. M., Darling, W. G., Nkotagu, H., Gooddy, D. C., Smedley, P. L., and Tyler-Whittle, R. A.: Environmental indicators of recharge to basement aquifers of Tanzania [abstract], in: Groundwater recharge assessment: are we any closer to an answer?, Geological Society, 20-21 May 2009, University of East Anglia, 2009.

20 Mileham, L., Taylor, R., Thompson, J., Todd, M., and Tindimugaya, C.: Impact of rainfall distribution on the parameterisation of a soil-moisture balance model of groundwater recharge in equatorial Africa, J. Hydrol., 359, 46-58, 2008.

Mohammed, Y. A., Bastiaanssen, W. G. M., and Savenije, H. H. G.: Spatial variability of evaporation and moisture storage in the swamps of the upper Nile studied by remote sensing techniques, J. Hydrol., 289, 145-164, 2004.

Mohamed, Y. A., van den Hurk, B. J. J. M., Savenije, H. H. G., and Bastiaanssen, W. G. M.: Hydroclimatology of the Nile: results from a regional climate model, Hydrol. Earth Syst. Sci., 9, 263-278, doi:10.5194/hess-9-263-2005, 2005.

Nicol, A.: The Nile: Moving beyond cooperation, UNESCO-IHP, Technical Documents in Hydrology, PC-CP series, 16, 1-14, 2003.

Ó Dochartaigh, B. E., MacDonald, A. M., Darling, W. G., Hughes, A. G., Li, J., and Shi, L.: Determining groundwater degradation from irrigation in desert-marginal northern China, $\mathrm{Hy}-$ drogeol. J., in press, 2010.
HESSD

7, 4501-4533, 2010

\section{Interpretation of \\ GRACE data using a groundwater recharge model}

H. C. Bonsor et al.

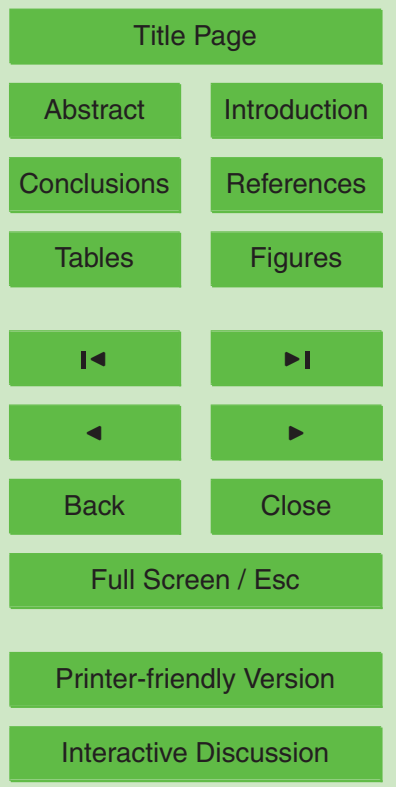


Penman, H. L.: Natural evaporation from open water, bare soil and grass, Proc. R. Soc. London, Series A, 193, 120-145, 1943.

Persits, F., Ahlbrandt, T., Tuttle, M., et al.: Maps Showing Geology, Oil and Gas Fields and Geological Provinces of Africa, USGS Open-file Report, 97-470A, 1997.

5 Rodell, M., Velicogna, I., and Famigletti, J. S.: Satellite-based estimates of groundwater depletion in India, Nature, 460, 999-1002, doi:10.1038/nature08238, 2009.

Rodell, M., Famigletti, J. S., Chen, J. Seneviratne, S. I., Viterbo, P., Holl, S., and Wilson, C. R.: Basin scale estimates of evapotranspiration using GRACE and other observations, Geophys. Res. Lett., 31, L20504, doi:10.1029/2004GL020873, 2004.

10 Schmidt, R, Schwintzer, P., Flechtner, F. Reigber, Ch., Guntner, A., Döll, P., Ramillien, G., Cazenave, A., Petrovic, S., Jochmann, H., and Wunsch, J.: GRACE observations of changes in continental water storage, Global Planet. Change, 50, 112-126, 2006.

Sutcliffe, J. V. and Park, Y. P.: The Hydrology of the Nile, IAHS Special Publication, 5, IAHS Press, 1-160, 1999.

Sutcliffe, J. V.: Comment on 'Spatial variability of evaporation and moisture storage in the swamps of the upper Nile studied by remote sensing techniques' by Y. A. Mohamed et al., 2004, J. Hydrol., 314, 45-47, 2005.

Syed, T. H., Famiglietti, J. S., Chen, J., Rodell, M., Seneviratne, S. I., Viterbo, P., and Wilson, C. R.: Total basin discharge for the Amazon and Mississippi River basins from GRACE and 20 a land-atmosphere water balance, Geophys. Res. Lett., 32, L24404, 2005.

Tapley, B. D., Bettadpur, S., Ries, J. C., et al.: GRACE measurements of mass variability in the Earth system, Science, 305, 503-505, 2004.

Taylor, R. and Howard, K.: Groundwater recharge in the Victoria Nile basin of East Africa: support for the soil-moisture balance method using stable isotope and flow modelling studies, J. Hydrol., 180, 31-53, 1990.

UNESCO: Africa Geological Map Scale (1:5000 000), 6 Sheets, UNESCO, Paris, 1991.

Vallet-Coulomb, C., Legesse, D., Gasse, F., Travi, Y., and Chernet, T.: Lake evaporation estimates in tropical Africa (Lake Ziway, Ethiopia), J. Hydrol., 245, 1-18, 2001.

\section{HESSD}

$7,4501-4533,2010$

\section{Interpretation of GRACE data using a groundwater recharge model}

H. C. Bonsor et al.

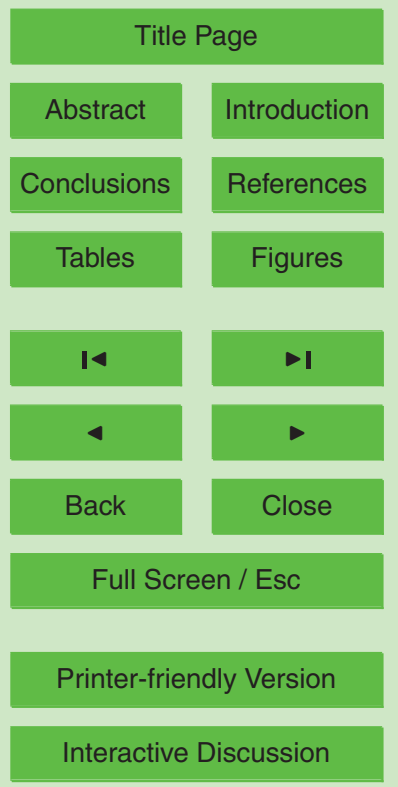


Table 1. Calibration results of the ZOODRM model based on modelled annualised discharge in 2003.

\begin{tabular}{lllll}
\hline $\begin{array}{l}\text { Annual discharge } \\
\left(\mathrm{km}^{3} / \mathrm{yr}\right)\end{array}$ & Aswan & Dongola & Bahr el Jebel & Lake Victoria \\
\hline Observed & 58.4 & 69.0 & 48.3 & 38.5 \\
Modelled & 60.1 & 80.6 & 69.1 & 42.6 \\
\hline
\end{tabular}

\section{HESSD}

7, 4501-4533, 2010

Interpretation of GRACE data using a groundwater recharge model

H. C. Bonsor et al.

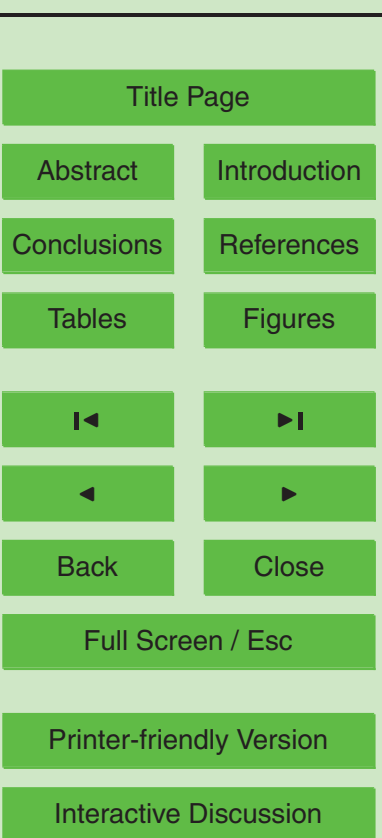




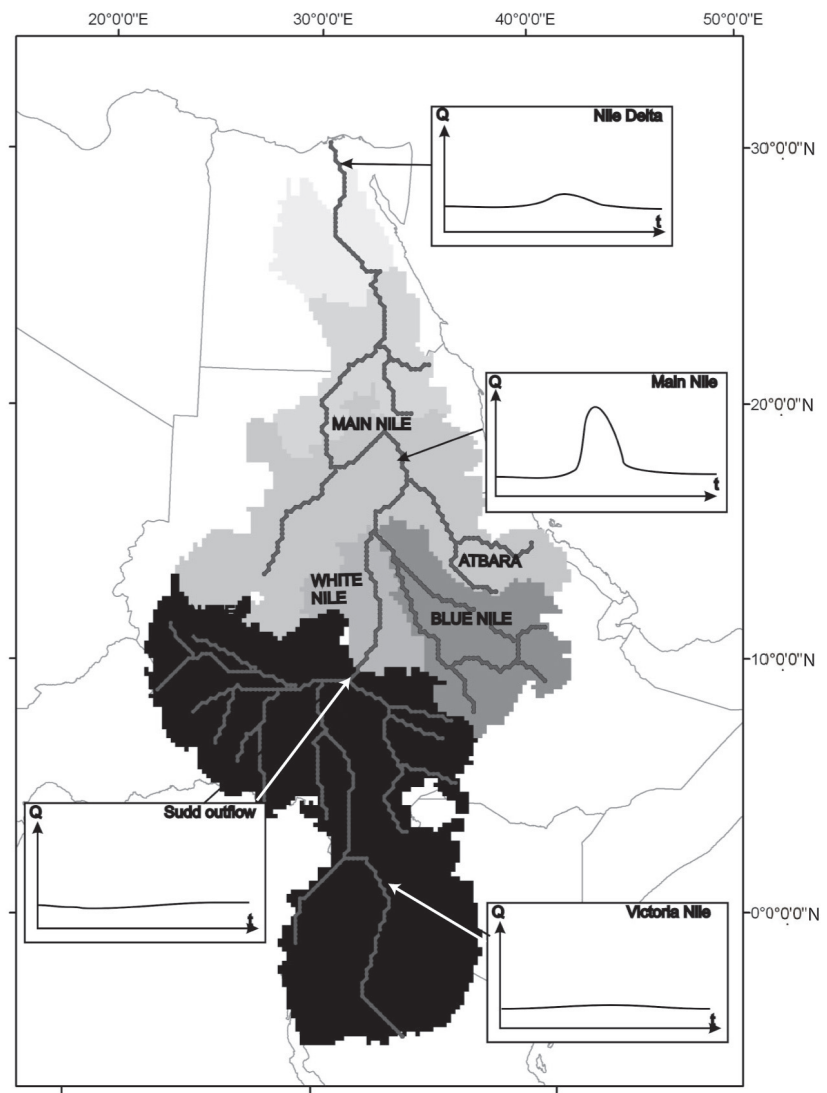

Fig. 1. Major sub-catchments of the Nile Basin: Victoria Nile, Sudd wetland, White Nile, Sobat, Blue Nile, Atbara and the Main Nile. Annual hydrographs indicate the seasonal pulse of discharge in the Main Nile river, downstream of the Sobat, Blue Nile and Atbara tributaries. In contrast outflow from the Sudd provides a constant annual baseflow to the Nile. Note all hydrographs display a typical hydrological year, and all discharge scales on the plots are the same.
HESSD

$7,4501-4533,2010$

Interpretation of GRACE data using a groundwater recharge model

H. C. Bonsor et al.

Title Page

Abstract

Introduction

Conclusions

References

Tables

Figures

14

$\rightarrow$

4

Back

Close

Full Screen / Esc

Printer-friendly Version

Interactive Discussion 


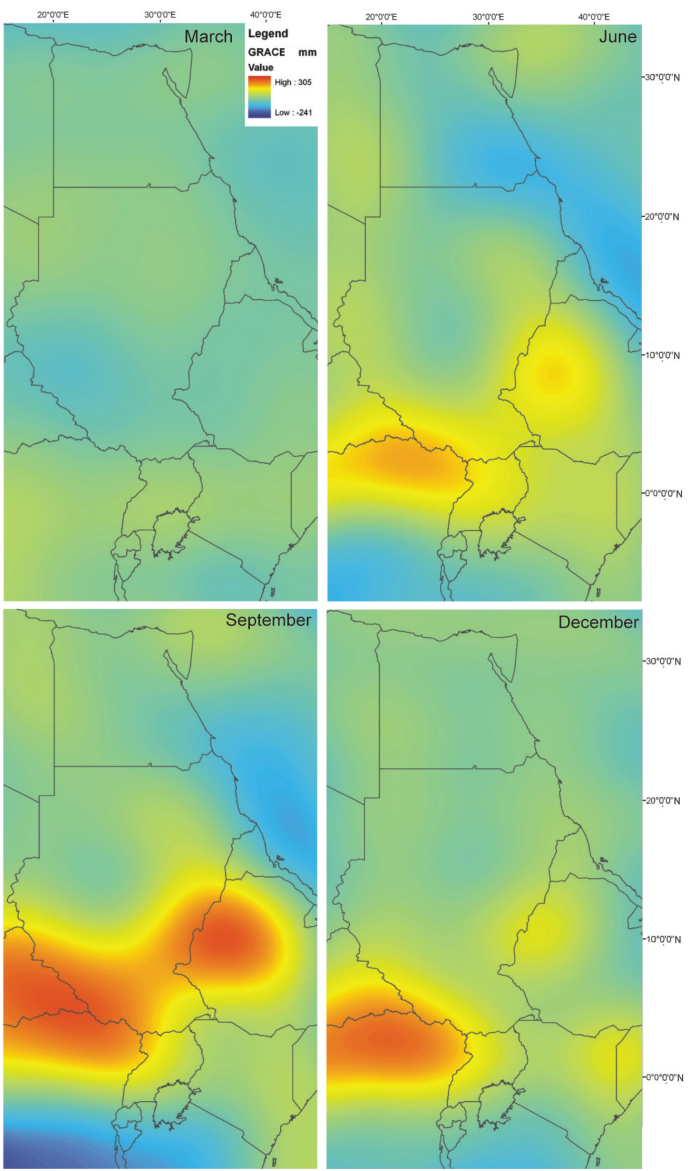

Fig. 2. GRACE data for the Nile Basin, inferred to relate to changes in terrestrial water storage mass changes. Each month of GRACE data reflects the change in total stored water mass, relative to stored water mass in March 2004 (the driest hydrological month of the modelled period).

\section{HESSD}

$7,4501-4533,2010$

\section{Interpretation of GRACE data using a groundwater recharge model}

H. C. Bonsor et al.

\section{Title Page}

\section{Abstract}

Introduction

Conclusions

References

Tables

Figures

14

4

Back

\section{Full Screen / Esc}

Printer-friendly Version

Interactive Discussion 


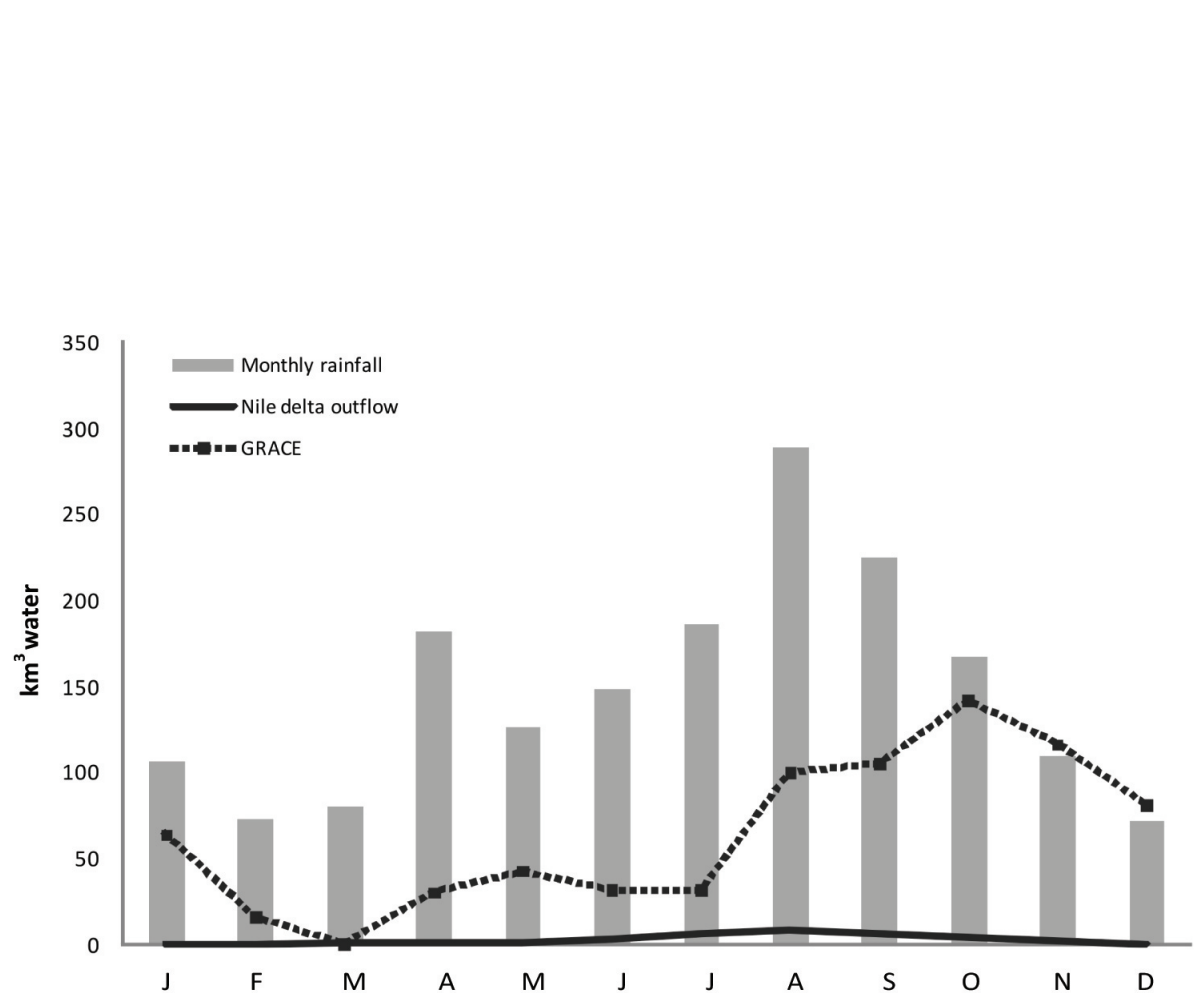

Fig. 3. Comparison of monthly rainfall, to the monthly river outflow to Mediterranean Sea, and monthly GRACE data (presented as water volume relative to March 2004) for 2004.

Interpretation of GRACE data using a groundwater recharge model

H. C. Bonsor et al.

Title Page

Abstract

Introduction

Conclusions

References

Tables

Figures

14

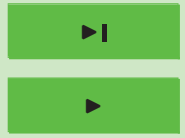

Back

Close

Full Screen / Esc

Printer-friendly Version

Interactive Discussion 


\section{HESSD}

$7,4501-4533,2010$

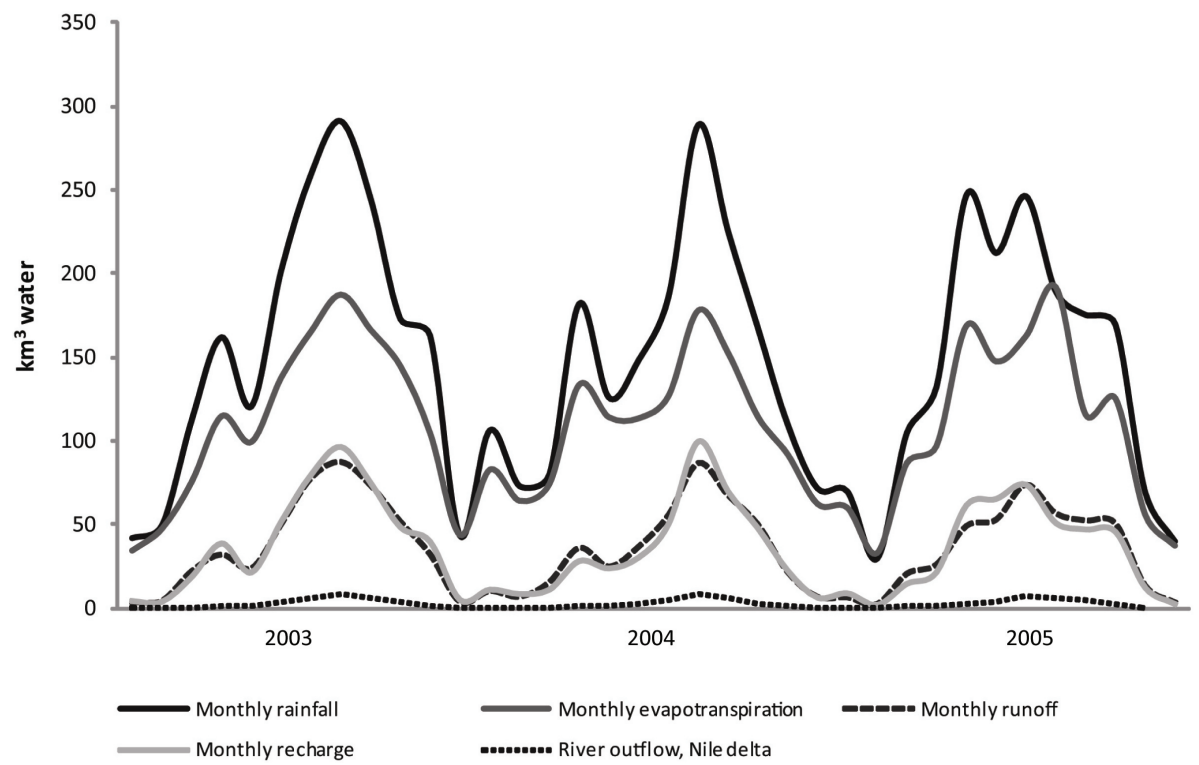

Fig. 4. Monthly volumetric estimates of the partitioning of rainfall within the Nile Basin between the main components of the water cycle. Soil moisture is not displayed on the plot, because the ZOODRM model only outputs the monthly change in soil moisture water mass, rather than total monthly soil water mass - a direct comparison to the other modelling results would therefore be invalid.

\section{Interpretation of GRACE data using a groundwater recharge model}

H. C. Bonsor et al.

Title Page

Abstract

Conclusions

Tables

14

4

Back

Full Screen / Esc

Printer-friendly Version

Interactive Discussion 


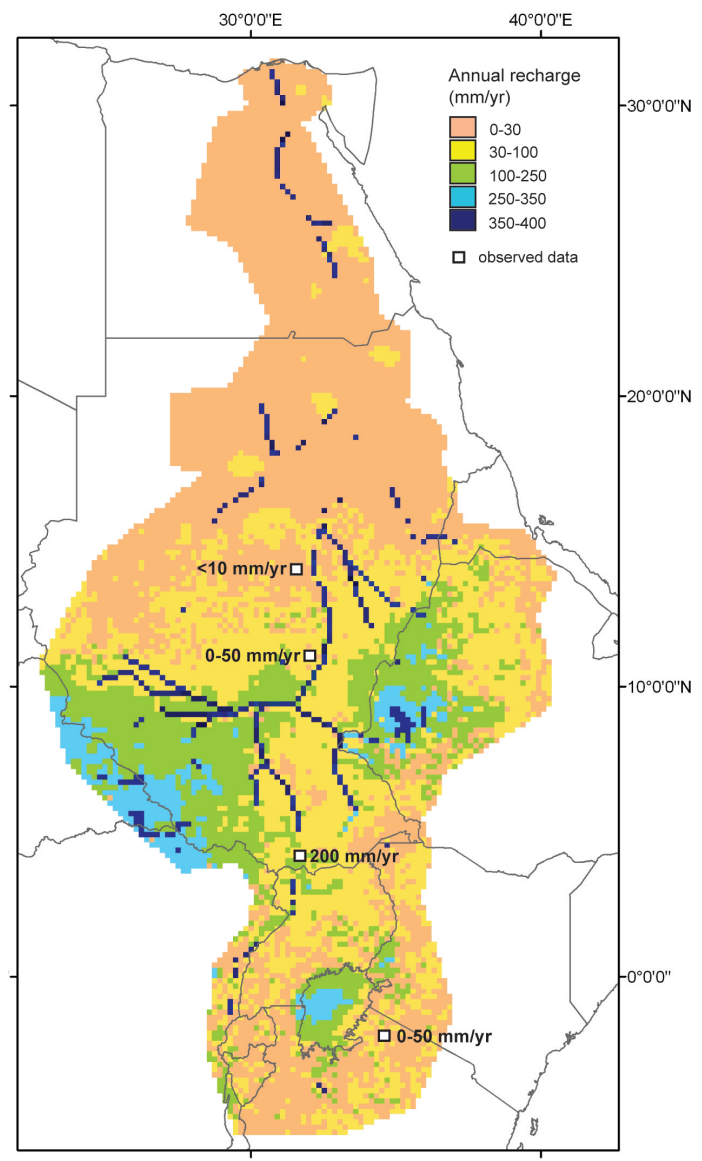

Fig. 5. Average annual groundwater recharge map of the Nile Basin. The data points and values on the recharge map represent annual recharge values determined from local studies by other authors based on isotope and chloride concentrations in the groundwater.

\section{HESSD}

$7,4501-4533,2010$

\section{Interpretation of GRACE data using a groundwater recharge model}

H. C. Bonsor et al.

Title Page

Abstract

Conclusions

Tables

14

4

Back
Introduction

References

Figures

$>$ I

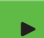

Close

Full Screen / Esc

Printer-friendly Version

Interactive Discussion 


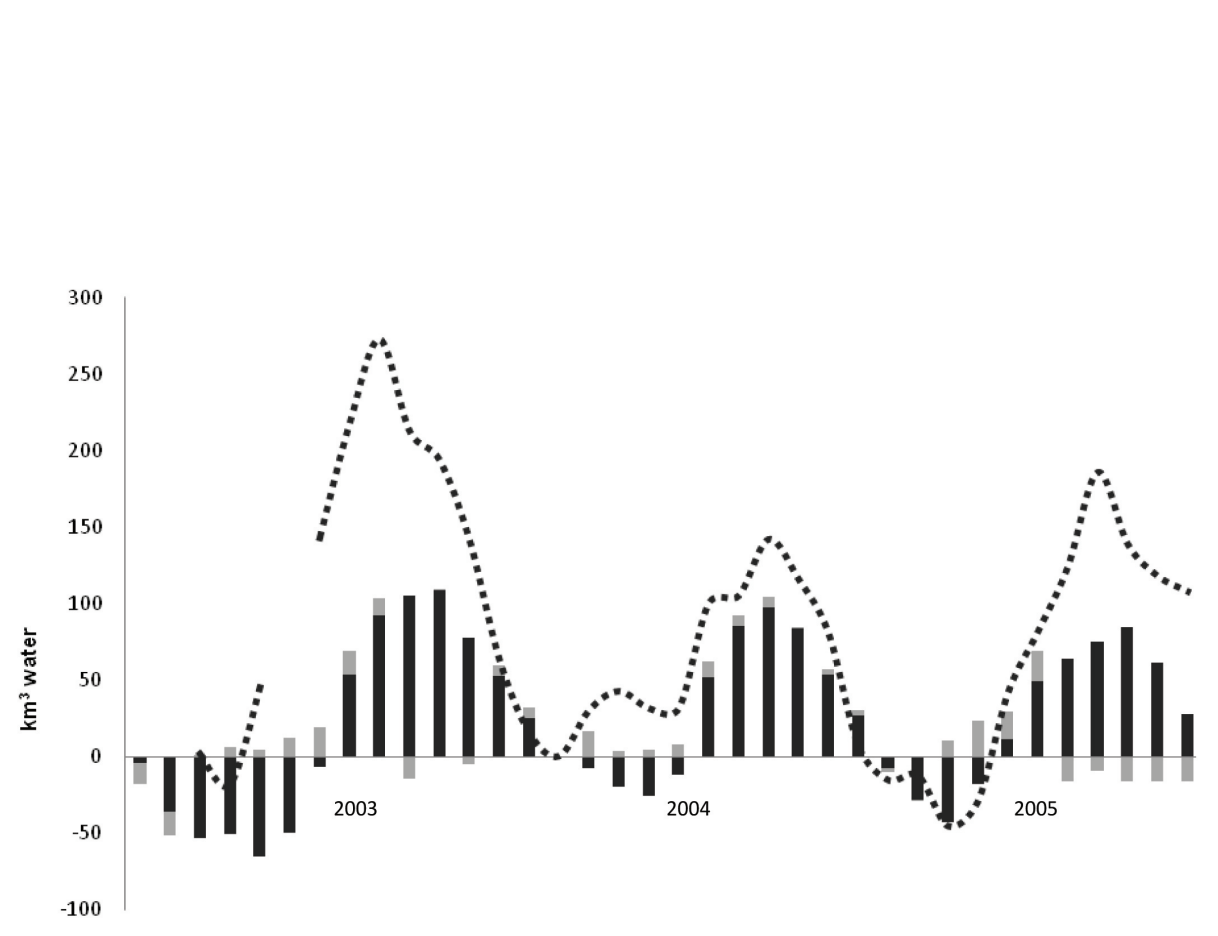

\section{HESSD}

7, 4501-4533, 2010

\section{Interpretation of GRACE data using a groundwater recharge model}

H. C. Bonsor et al.

\section{Title Page}

Abstract Introduction

Conclusions References

Tables

14

4

Back

\section{Figures}

$>$ I

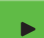

Close storage and soil moisture. The groundwater and soil moisture storage changes are cumulated values which have been normalised to March 2004, like the GRACE data.

\section{Full Screen / Esc}

Printer-friendly Version

Interactive Discussion 


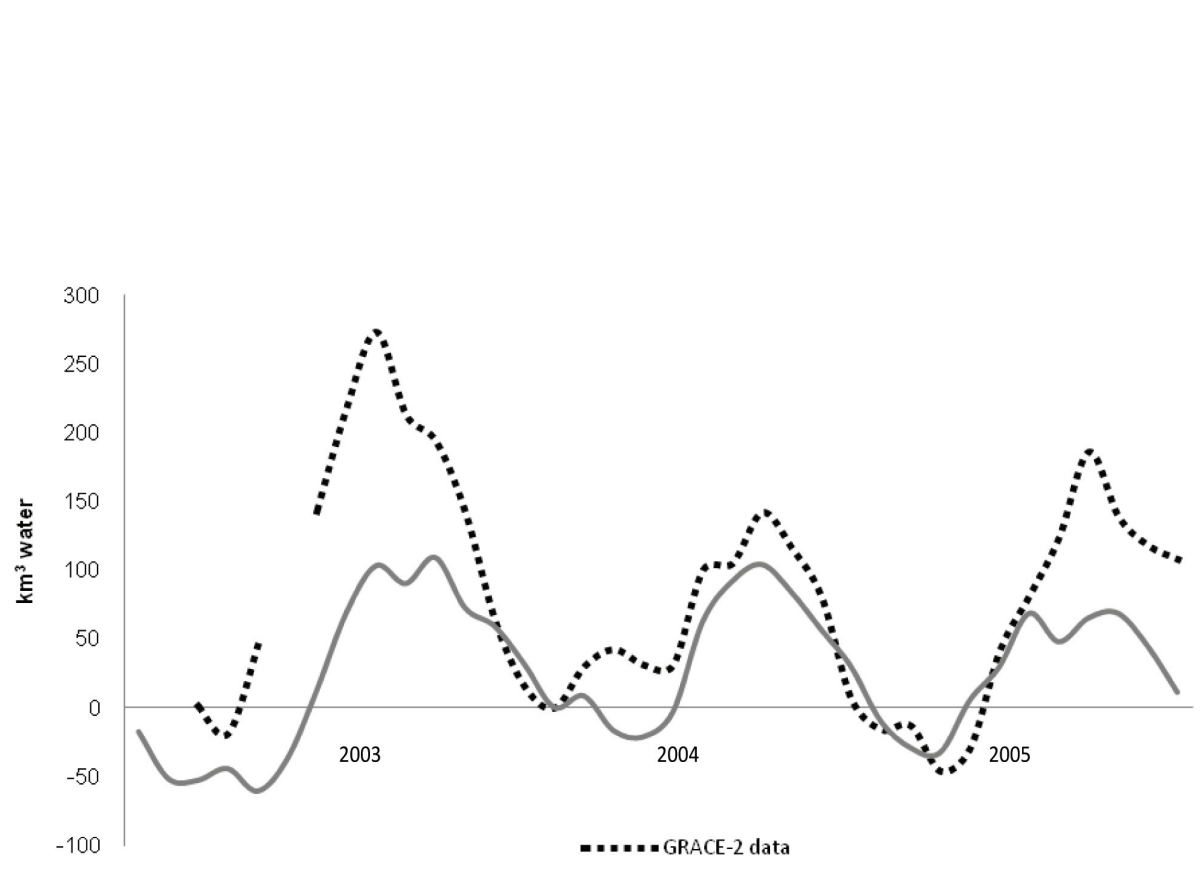

\section{HESSD}

$7,4501-4533,2010$

\section{Interpretation of GRACE data using a groundwater recharge model}

H. C. Bonsor et al.

Water storage in soil moisture and groundwater recharge

Fig. 7. Comparison of GRACE data for the Nile Basin to the total water volume stored in soil moisture and groundwater recharge. In drier years (e.g. 2004) when the volume of seasonal runoff water and surface water storage is less, the total water storage mass variation in the basin, is comprised predominantly of seasonal change in soil moisture and groundwater storage.

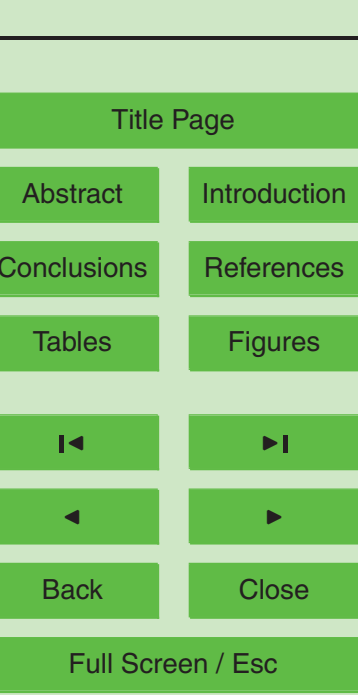

Printer-friendly Version

Interactive Discussion 